\title{
Book of the Lost Narrator: Re-reading the 1977 Silmarillion as a Unified Text ${ }^{1}$
}

\author{
Dennis Wilson Wise
}

\section{Introduction}

In Tolkien's famous essay about Beowulf and the critics, he chides his colleagues for failing to treat the poem as a literary object; they neglect its aesthetic beauty while snuffling around for philological or genealogical data. In a way, I apply much the same point to readers of Tolkien's own 1977 Silmarillion. Christopher Tolkien had once written that he treated the 1977 text "of the same order as the writings published by my fatherhimself" (UT3), a "completed and cohesive entity" rather than "a complex of divergent texts interlinked by commentary" (1). Christopher Tolkien later distanced himself from this position, deeply regretting that he "attached no importance" to his father's concerns about presentation ( $L T$ I xi) and thereby left for The Silmarillion "no suggestion of what it is and how (within the imagined world) it came to be" (xii). Understandably, Tolkien scholars followed this path, discounting The Silmarillion for the much more authentic-seeming History of Middle-earth. Additionally, they seethe 1977 text, though powerful in places, as a product rife with flaws, uneven in structure and detail, sadly heterogeneous in style, and furthermore marred by the editor's unavoidable hand.

I wish to present an alternative reading of the 1977 text. Like Gergely Nagy, but for profoundly different reasons, I believe that The Silmarillion, "exactly as it stands in the 1977 text, is a profound work"("Adapted" 35), a narrative and rhetorical masterpiece. Ido not value The Silmarillion forits hint of avant-texts ortextual prehistory, its echoes of oral folklore transformed into written forms. Nor do I see the work's supposed flaws as mimetically reproducing this transformation - in fact, I argue against there being flaws at all. Instead, I see The Silmarillion as a "completed and cohesive entity," a single unified textin which all five stories are structurally linked and thematically interlocked, where all the seeming inconsistencies and strange silences are actually part of an intentional rhetorical strategy devised by a single, anonymous author of high moral seriousness.

${ }^{1}$ This article originally appeared in Tolkien Studies, vol. 13, 2016, pp. 101-24. Project Muse, doi:10.1353/tks.2016.0008 
Perhaps to the dismay of some, Ialso charge that this heavynarratorial hand renders questionable the "veracity" of the history he writes. Indeed, I see this anonymous writer as eerily similar to Geoffrey of Monmouth, someone who clearly worked from existent "sources, oral or written, in the British tradition" ( Jankulak 14) but for whom "writing true accounts aboutreal events" was nothis primeintention (2). He modified - even invented - the historical record as the situation demanded. Ultimately, the writer of The Silmarillion, likeGeoffrey of Monmouth, had a fundamentally literary purpose, a purpose higher than "true history": the guidance of the reader toward the life rightly led.

My argument proceeds as follows. Section 2 deals with two preliminary matters: (a) the importance of treating The Silmarillion as an autonomous yet canonical text and (b) the "compilation" thesis against which my "unified text" thesis operates. In section 3, I analyze two brief passages representative of the whole. These passages, I argue, constitute a tour de force of careful rhetorical manipulation and guidance. Section 4 tackles the objection that an inconsistency of narrative style and level of detail indicates, contra my argument, a compilation of lost texts. Finally, section 5 shows how the final two stories in The Silmarillion, the "Akallabêth" and "Of the Rings of Power," form codas thematically vital to the Silmarillion's structure as a whole.

\section{Complicating Factors}

\subsection{The Canonicity of the 1977 Silmarillion}

When critics dismiss or discount the published Silmarillion, they generally do so from one of two poles. Brian Rosebury represents the first. Hebaldly states that Tolkien'sreputation must "very largelyrest on The Lord of the Rings" (8), implying that his other works, such as The Silmarillion, do not merit much attention. The other pole of critics discount the bookinfavor of more "authentic" posthumous writings. The work of Verlyn Fliegerand Douglas Charles Kane seems applicable here. According to Vladimir Brljak, Fliegertends to view Tolkien's entire mythology, "rather than just the published, authorized works, as the proper, or at least as the ultimate, locus of a Tolkien critic's attention" (5). Indeed, Flieger states explicitly that the 1977 text "gives a misleading impression of coherence and finality, as if it were a definitive, canonical text, whereas the mass of material from which that volume was taken is a jumble of overlapping and often competing stories, annals, and lexicons"(63, emphasis added). Likewise, Kane argues that the 1977 text pushes "thelimits of editorial 
intervention" (55), illicitly removing elements essential to Tolkien'sauthorial intention (narrative frame, women's roles, etc.), which thereby makes Christopher Tolkien's edited text "a lesser work"(252). Almost worse is the opinion of Charles Noad, who is grateful that the 1977 text appeared as it was only because "a more scholarly edition at that time wouldalmostcertainly have precluded laterpublication of The History of Middle-earth" (65).

The founding intuition behind this dismissal is perfectly understandable: the 1977 Silmarillion is a mediated text. If it really is just a "collaborative effortbetween J.R.R. Tolkien and his third son," as Jason Fisher argues (133), then theHistory of Middle-earth at leastpossessesthe virtue of displaying Tolkieninhisfullunedited glory. Ifthis considerationis deemed paramount, any extended exegesis of The Silmarillion itself seems like a vain and idle exercise.

Nonetheless, readers and scholars unavoidably do treat The Silmarillion as canonical Tolkien. This seems like the most important takeaway from The Silmarillion: Thirty Years On, the only volume devoted solely to the 1977 text. For Allan Turner, the book stands "as the canonical work, the standard against which all variations are measured" by virtue of "its status as the first and most unified form of the mythology" (ii). Jason Fisher concurs. For "good or ill, the work now stands as something like acanonical text, despite the unavoidable intrusions of its editor" (113). Indeed, practical considerations - if nothing else - guarantee the published text's importance. It "has a far larger audience than the exceedingly complicated welteroftextsin The History of Middle-earth" and sorepresents formost readers "the standard, authoritative source of 'information' about the ElderDays”(Agøy 141). Thus, the 1977 text ought to be accorded a special status notlikewise accorded to the otherposthumous publications. As a result, dismissing The Silmarillion as either lacking literary merit or being misleading or nonrepresentative creates an excessively thorny issue.

As aside note, literary history does give a nobleprecedent for treating something like The Silmarillion as canonical for its author. Most Shakespearean scholars categorize King Lear as one of the Bard's four central plays, yet the King Lear commonly taught to undergraduates was never actually "authorized" by Shakespeare himself. The play exists in two versions only, the 1608 quarto and the 1623 First Folio. Since each version contains valuable scenes missing from the other, most modern productions work off a merged or conflated text-a text never performed in Shakespeare's lifetime or specifically authorized by Shakespeare himself. The justification, of course, is that the conflated version 
offers a betterand more interesting play than either the quarto or First Folio versions alone. Without being too tongue-in-cheek, textually speaking, we therefore might dub The Silmarillion as "Tolkien's King Lear."

\subsection{A Compendium, the Impression of Depth, and the Unified Text Thesis}

The Silmarillion has no narrative framework-nothing in the text itselfto indicate how readersought to approachit. Nonetheless, partly thanks to Lord of the Rings, partly thanks toclear authorial and editorial intention, mosthave tried reading it through the "lost texts"technique. Agøy defines this technique as "the pretense that the work in front of the reader is not really written by a modern author, but consists on translations and retellings of texts far older" (140). We may also call the lost texts technique the "compilation thesis," a direct antithesis tomy "unified text" thesis. Closely related to the compilation thesis-but not inextricably related to it - is what some critics deem the essence of Tolkien's literary value: his impression of depth, his sense that countless texts and contexts lie behind the thing we are reading. As alluded to earlier, the compilation thesis rests on nearly undeniable foundations. Christopher Tolkien makes this point in his foreword. "My father," he writes, "came to conceive The Silmarillion as a compilation, a compendious narrative, made long afterward from sources of great diversity (poems, and annals, and oral tales) that had survived in agelong tradition" ( $S$ viii). Tolkien himself had formulated his artistic intentions early. For example, as a young man he warned against reading the Finnish Kalevala as a "national epic" akin to those of Europe's more southerly countries; the Kalevala has to be readas a collection of tales rather than a unified whole. ${ }^{2}$ We "can have yourgargoyles onournoblecathedral; butnorthern Europe has lost much through too often trying to build Greek temples" (Tolkien, "Story of Kullervo" 265).

Following such leads as these, Gergely Nagy has claimed that The Silmarillion can be read as a "story about stories, both in the historical and a metafictional sense"("Adapted"36). Because the 1977 textreferences several other source texts within its pages, we get the hint of textual retextualizations. ${ }^{3}$ These references can be to pseudo-texts (referring totexts thatdonotexistand that Tolkienneverwrote), real-and-also-extant sources (appearing in the History of Middle-earth), and possibly even real-but-lost sources-all of whichmirrors the problems of medieval and philological scholarship in the Primary World. ${ }^{4}$ An immense sense of depth results - and inconsistencies of style and narrative detail within the 1977 textare explainable by the diversity of sources. The styles, Nagy claims, "change [even] within units of the text" ("Adapted" 20). This diversity 
also leads to "a striking mix of limited knowledge and seeming omniscience" in different passages, which possibly indicates "atleast two different Narrators, who are voicing different perspectives, probably stemming from different points in time" (Agøy 151, 152).

Building on Nagy's work, Michael D. C. Drout, Namiko Hitotsubashi, andRachelScaveraarguethat the "impressionof depth" isactually increased by the text's various inconsistencies, both logical and stylistic. These inconsistencies hint "to the reader, perhaps even at a subconscious level, that the text is not the pure invention of a single author but rather a compilation of the work of multiple writers over many years - exactly what, by adopting the conceit that he is translating the Red Book of Westmarch, Tolkien claims his work to be" (180). On onehand, a single authormay remove contradictions and smooth out style during revision. On the other hand, a compiler has less freedom than an author - he must take texts largely as he finds them.

The glorification of such inconsistencies, however, strikes me as overly sanguine.In contrast to Nagy and Droutetal., the text's apparent problems frustrate Nils Ivar Agøy more than excite him. For him, reading The Silmarillion as a compilation of lost texts does "notsomuch provide depth or verisimilitude as confusion and disappointment" (160). Even Verlyn Flieger, who privileges "The Silmarillion" over the 1977 Silmarillion, acknowledges the limitations of the pseudo-translation (or lost texts) framework. It may best be "seen as an authorial conceit but not a substantial structural factor" because too "many things will not fit comfortably into the concept - narrative voice, point of view, theamount of knowledge each of these 'authors' could havehad at any one time" (79). Indeed, I think Nagy, Droutetal., and many other like-minded critics fall prey to the tendency noted in section 2.1 - discounting the published 1977 textinfavorofits hypotexts or avant-textes, ${ }^{6}$ the prehistory of the final product. ${ }^{7}$ If we take The Silmarillion as acanonicalwork, as Ithink wemust, itbehoovesustoread it in the best possible light — and rather than glorifying the text's alleged flaws and inconsistencies, as Nagy and Drout etal. seem to do, or lamenting them, as Agøy does, my unified text theory proposes to resolve them.

Indeed, a critical concern with the hypotexts, which leads to the "gross heterogeneity" of The Silmarillion's prose style (Drout et al. 184) interpolations, pseudo-interpolations, and remnants of source materialsurviving into the final text - seems like an exercise fraught with peril. The 19th-century doctrine of Liedertheorie held that most epics, including the Greek ones, had begun as nonliterate "lays" or "ballads," and critics (especially German critics) 
often sought — vainly — to separate the authentic lays from the later literary interpolations. Drout himself acknowledges the dangers of such an approach when miningIdaGordon'sedition of The Seafarer forpossibleinfluences fromTolkienDroutadmits finding himself attributing all "themost insightful emendations and suggestions to" Tolkien ("J.R.R. Tolkien's Medieval" 159). Yet it may be answered that the History of Middle-earth allows us objectively to double-check our allegations of interpolation. Let me suggest that that is only partially true. Take the sentence, "Theeagle has landed.”This sentence will have onemeaning when uttered in a national park, another meaning when spoken to someone familiar with the novels of Jack Higgins, and yet another when discussing Apollo 11.Inother words, contextlargely determines meaning. If a sourcetext contains acertain passage, and another textrepeats the same passage verbatim, the meaning of those two passages will nonetheless change because of differing surrounding materials. Meaning will change, not only because the passage appears in a new context but because the reader will bring to the passagenew expectations-genre expectations, biographical expectations, and so on. The transplanted passage, furthermore, will be read in the light of the new workas a whole. For this reason, we cannot assume a simple transmission of meaning or intent, even if The Silmarillion's writer (or Tolkien in the primary world) had copied some passages word by word from earlier texts. Instead, we should ask how the target text changes and modifies the transplanted passage - and how, correspondingly, the transplanted passages change and modify the target text as a whole.

Sowhereas others mightseea gross heterogeneity of styles, textual inconsistencies, textual flaws, or strange discrepancies in levels of narratorial omniscience, I much prefer to see deliberately placed oddities that must be fitted into the whole and explained rather than explained away. Such a reading, I suggest, will effectively make the 1977 book a stronger book. We need not give up the "impression of depth" because, afterall, the text does explicitly refer to several other texts. Still, I suggest refocusing our attention. The writer of The Silmarillion clearly worked from source materials and like Geoffrey of Monmouth, worked for a higher purpose. He wrote a single unified text to accomplish this focus, and this means we should give up the frustrating and confusing compilation thesis.

Tothat end, let us examine two concrete passages - and find out how they operate rhetorically. To the issue of the high craft of The Silmarillion we now turn.

\section{Two Passages}


Both passages appear late in the "Quenta Silmarillion." The first depicts a conversation between the last two living sons of Fëanor, Maedhrosand Maglor; the second describes Morgoth's finalcapture. Initially, I will attempt to phrase my argument along "text-active" lines - the text does this, the text does that. I do not wish to presuppose the existence of a narrator/author-figure, since that is what I wish to prove.

Here, then, is the first passage. Maedhros and Maglor are trying to decide if they should fulfill their oath to regain the Silmarils at any cost. TheElvish host from Valinor currently possesses them, having just taken them from Morgoth in the War of Wrath. Maglor, who elsewhere has been described as "sick and weary with the burden of the dreadful oath" ( $S$ 247), initiates the dialogue:

"Theoath says not that we may notbideourtime, andit maybe that in Valinor all shall be forgiven and forgot, and we shall come into our own in peace."

ButMaedhros answered that if they returned to Aman but the favour of the Valarwere withheld from them, then theiroath wouldstill remain, butits fulfillment be beyond allhope; and he said, "Whocan tell to what dreadful doom we shall come, if we disobey the Powers in theirown land, or purpose ever to bring war again into theirholy realm?" YetMaglor still heldback, saying: "If Manwë andVarda themselves deny the fulfillment of an oath to which we named them in witness, is it not made void?"

And Maedhros answered: "But how shall our voices reach to Ilúvatar beyond the Circles of the World? And by Ilúvatar we swore in our madness, and called the Everlasting Darkness upon us, if we kept not our word. Who shall release us?"

"Ifnone can release us," said Maglor, "then indeed the Everlasting Darkness shall be our lot, whether we keep our oath or break it; but less evil shall we do in the breaking." (S 253)

Here endsthedialogue.Maglor'slastargumenttakes pride of place at the end. The passage's moral intent seems clear: when faced with two awful choices, choose the lesser of two evils. Break the oath, give up the claim to the Silmarils. Maglor's words begin the conversation; his words end it. Two separate objections are offered by Maedhros; Maglor answers them.

Yet, though the dialogue ends here, the action does not. Immediately we read, "Yet [Maglor] yielded at last to the will of Maedhros, and they took 
counsel togetherhow they should lay hands on theSilmarils" (S 253). This final resolve seems odd. Maglor, who espouses the righteous viewpoint, has somehow lost the argument. Immediately afterward, the brothers enter Eönwë's camp, murder the guards, and steal the two remaining Silmarils. But why? Let us examine these two excerpts together. The bulk of the passage - 202 wordsargues forbreaking the oath. Maedhros'sobjections and Maglor's rebuttals are given in direct speech, which highlights them. (Readers tend to privilege dialogue, hence mass-market paperbacks are mostly dialogue.) Nonetheless, the passage's final sentence - a mere 23 words, or about 10 percent of the totalsubverts the previous 90 percent.

Here is the situation. An "immoral" argument, presented by Maedhros, has defeated a "moral" argument. What is the immoral argument? We donot know; the text refuses to tell. It earlier seems willing to summarize an argument in indirect speech ("But Maedhros answered that") but, for some reason, nothere. Its strategy is silence; it merely tells that Maglor "yielded at last ${ }^{8}$ to the will of Maedhros." It does not indicate why. Perhaps we could guess at Maglor's psychology, tell ourselves a story about a domineering older brother or a lack of self-confidence, possibly even a lack of inner fortitude, but such stories would be us speaking and not the text. Nor would such stories explain why the text chose to devote 202 words to a failed argument and then suppress the reason for its failure.

Itisalmostasifthe textdoes notwant thereadertojudgethe arguments on their own respective merits. Consider the fundamental elementinrational discourse: the fair presentation of both sides. Fora mediator to sway the reader to one position unfairly, either through ad hominems or straw-man arguments or whitewashing counterarguments, is to manipulate the reader. The text seems fearful of letting the reader judge the respective arguments on their own merits. Perhaps the reader, hearing Maedhros at length, will come to adopt Maedhros's point of view? After all, Maglor-who did hear this argument — eventually adopted Maedhros's point of view. Maedhros corrupted Maglor; perhaps the text does not want Maedhros to corrupt the reader as well. ${ }^{9}$

Let us notice something else. Allegedly, this is a private conversation between two brothers; the text does not mention anyone else as present. On what authority does the text present this conversation? An earlier passage further calls everything into question: "Of the march of the host of the Valar tothenorthof Middle-earthlittle is said in any tale; for among them went none of those Elves who had dwelt and suffered in the Hither Lands, and who made the histories of 
those days thatstill are known; and tidings of these thingsthey only learned long afterwards from their kinsfolk in Aman" ( $S$ 251). The text admits that no reliable primary documentation exists for the War of Wrath. The few extant documents come only at secondhand, composed from information "learned long afterwards." As any historian can attest, memory being what it is, even firsthand accounts can be unreliable, especially in emotionally traumatic situations like war. Accounts coming secondhand multiply the unreliability exponentially — details are added,memories change, individuals tend to overemphasize their own roles, and so on. (Gut instinct tells me that Tolkien had originally written this passage to give some explanation for how these events might become known to posterity; but, if so, the "explanation" seems to undermine his intention dreadfully.) Taking all this into account, how can the flesh-and-blood writer of the original dialogue have known with such precision the details of this unwitnessed conversation, occurring within the context of an entire warforwhichnosolidly reliableaccounts exist?

Let me propose that whoever physically wrote these passages down in the fictional world had simply invented the entire conversation. (And now I begin to drop the pose of "text-active" language.) We know that the Maedhros-Maglor passage, by itself, is no "innocent" rendering of a conversation - it deliberately suppresses pieces of dialogue that certainly occurred in the event-story; the strategy makes Maglor's views prominentwithoutcalling attentionto theirfailure. So whoeverwrote this passage - and someone obviously did - had a clear moral purpose: he wanted to uphold a certain ethical principle, the idea that — when faced with two evil choices - the lesser of two evils should be done.

Furthermore, the writer-narrator presumably knows that Maglor and Maedhros perished in some fashion, perhaps even abad fashion. (Major events like death are more easily cross-checked than others.) The writer also knows how easy it can be to write prophecies retroactively. Thus, he attributes to the brothers motivations thathe considers morally unworthy, and when those two die in unworthy fashion, the ethical principle that the writer wishes to uphold is miraculously upheld: lives lived in evil will to evil ends come.

In other words, the writer-narrator begins with the awful fates of Maglor and Maedhros and works backward, retroactively attributing poor choices or character flaws to explain those awful fates. He then takes the opportunitycreated, incidentally, by himself - to have Maglor articulate the lesson the reader ought to learn. The writer then composes the dialogue in such a way that unwary readers might gloss over thefact that Maglor, in theend, did not ultimately accepthis own argument. 10

If westartreading The Silmarillion alittle moresuspiciously, we may 
more easily notice the narrator's customary slyness. Let us take another example. It occurs deep in the mines below Thangorodrim. "There Morgoth stood at last at bay, and yet unvaliant. He fled into the deepest of his mines, and sued for peace and pardon; but his feet were hewn from under him, and he was hurled upon his face" ( $S$ 252). Morgoth, obviously, is The Silmarillion's whipping boy. There is no evil that does notsomehow originatein him. Correspondingly, the textalways attributes vice to him but never virtue. (Indeed, Melkor and Ungoliant are arguably responsible for the most exciting passage in The Silmarillion, the blighting of the Two Trees of Valinor, but the text will grant nothing like "fearlessness" to the enemy.) The passage just quoted follows suit. When Morgoth makes his last stand, the text describes that stand as "unvaliant." Again we ask, as we asked earlier, how does the writer of this passage know? Worse, his explicit value judgment ("unvaliant,"cowardly) is not consistent with the best practices of modern historiographic writing. For example, no modern historian would write, "Hitler killed himself like a coward to avoid capture by the Allies"- however laudable the sentiment, the bias of the text would be too clear. Our writer-narrator clearly makes no pretensions to be writing a scientific "true" history.

We might legitimately question some of the details of this capture, too. His "feet were hewn fromunder him" is a very specific detail. It is odd that the text can be specific about that and yet not be specific about who did the deed. In what was arguably the most glorious individual deed of the First Age, it seems exceedingly strange that no one was given credit for that deed. Weknow that Isildur, after all, slew Sauron to end the First Age. Weknow that a king of the Elves, Fingolfin, attempted to slay Morgoth. But the text's writer decides not to reveal who finally captured Arda's Satan.

The question of who finally slew Morgoth, of course, really has no answer within the 1977 text. We can speculate, though — and I think such guesses illustrate the ways in which we, as readers, need to question the writer of The Silmarillion. Perhaps the Elves of Valinor had no desire for personal glory, so never bothered to sing the praises of the captor toElvish historians. Or, perhaps, the captorcame from anonnoble house; the text's writer does seem to have a clear aristocratic bias. Or, mostinterestingly, perhaps the glorious capture of Morgoth was not really so glorious. In the chivalric tradition, granting mercy to foes who sue for peace is considered honorable. The captor denied Morgoth thatmercy.Is denying suchmercy really in line with the narrator's moral compass? I suggest not. ${ }^{11}$ So, assuming that the writer did not invent the scene out of whole cloth (always a possibility), perhaps thenarratordeliberately suppressesthenameof Morgoth'scaptor because those actions, no matter their context, worked against 
the narrator's larger moral project. He refuses to glorify - or let the reader glorify-someone who shamefully refused to grant an enemy mercy.

Such careful rhetorical maneuvering, I submit, is a general feature of The Silmarillion. Wecanbegin to seethenarrator'srhetoricalmaneuverings everywhere. Taking just one more quick example at random, whenMorgoth surprises the Noldorat the Second Battlein the wars of Beleriand, the Dagor-nuinGiliath, the text says, "The Noldor, outnumbered and taken at unawares [by Morgoth's armies], were yet swiftly victorious; for the light of Aman was not yet dimmed in their eyes" (S 106). On the face of it, unless the narrator's craft has successfully seduced the reader, this statement sounds ridiculous. "Possessing the light of Aman in one's eyes" is nota valid military principle. The narrator is setting Fëanor up for a downfall, sohe can hardly attribute military genius to the person responsible for the Kinslaying - even if that explanation seems more likely. Ironically, Fëanor soon dies in that same battle, slightly undercutting the wonderfulness of Aman light possession.

It should be noted that Idonot consider being "seduced" by the text necessarily a bad thing. What I call suspicious reading — or just paying attention to how the narrator manipulates the reader - is, in a way, the attempt toresist the irresistible suspension of disbelief that attends successfulsubcreation. Only by so doing, however,can we properlybegin to appreciate the art (from which we get artifice) that undergirds The Silmarillion as a whole. Thefollowing sectionshows how that artapplies even to those aspects that some critics deem most flawed.

\section{Different Styles in the Text}

One benefit of the compilation thesis is that it allows readers to salvage an allegedly flawed textcomposed by awriter they admire. Mostreaders, strangely, seem unwilling toargue that The Silmarillion is not actually flawed. Half apologetically, Christopher Tolkien ascribes to the compilation method such featuresas "the varying speed of the narrative and fullness of detail in different parts, the contrast (for example) of the precise recollections of place and motive in the legend of Túrin Turambar beside the high and remote account of the end of the FirstAge, when Thangorodrimwas brokenand Morgothoverthrown"( $S$ viii). 12 In otherwords, notonly does the style 13 vary among the five stories in the book, but the style can even vary inside one and the same story or chapter. We may detect Christopher Tolkien's unstated principle: if a text had been unified by a lone writer, then its narrative style and level of detail should remain consistent throughout.

Thus, reading The Silmarillion as a compilation seems like a neat 
solution - except, of course, thatitdoes notwork, as indicated in section 2.2. Another solutionis possible, however. Oddly enough,James Joyce provides a model. Each of Ulysses's 18 chapters is written in a radically different style-yet only one man managed to write them all. Although Tolkien had clearly never intended a radical heterogeneity of styles, since that contravened his traditional notion of good prose, he nevertheless accomplished just that. The question then becomes, as it does with Ulysses, how do the different individual styles contribute to the overall effect of The Silmarillion?

As my test case, I take the example provided by Christopher Tolkien - the stylistic differences between the Túrin Turambar legend and the War of Wrath. Just to repeat, the main discrepancy cited is narrative speed. From this discrepancy in speed derives the attendant problems of different levels of detail (faster narrative, fewer details) and how "close" the point of view seems to the events narrated. (Generally, the faster the summary, the higher and more remote its presentation.) To begin, let me state something with which few readers would disagree: these stylistic differences $d o$ exist. Ratherthan focus on what this stylistic diversity implies about compilation, however, I want to focus on what it implies for the reader - thatis, why the narrator might have chosen to narrate these different passages differently. Let us focus on the Warof Wrath. Within the War of Wrath is located - by Drout — an "eucatastrophic" moment, but this passage also comes under heavy fire by him. He considers the eucatastrophe "diminished" by how the text gives "more narrative space [to Maedhros and Maglor] than the victory itself ("Reflections" 44). Moreover, the waritself is flawed by its "very swift, skeletal narration"(44). ${ }^{14}$ All this might be laid at the feet of a careless editor (in the textual world, of course) and a consequence of the consequence of compilation of lost texts. 15

Yet an entirely different answer is possible. We can hypothesize that the narrator glosses so rapidly over the War of Wrath not only thanks to limited quality sources but because - fundamentally - the details of the war do not matter to him. The most important event is not the war itself or even the capture of Morgoth, which is anyway dishonorable, but themoral dilemmathatplagues Maglor. The narratorwants to get the war "over with" as soon as possible so he may tackle the issues that really matter. But does this not undercut the eucatastrophe of the War of Wrath itself? Not at all. Unlike Drout, I do not locate the eucatastrophic momentin the war. Rather,Ilocate it at the veryend of the Voyage of Eärendil. Specifically, these lines: 
Now when first Vingilot was set to sail in the seas of heaven, it rose unlooked for, glittering and bright; and the people of Middle-earth beheld it from afar and wondered, and they took it for a sign, and called it Gil-Estel, the Star of High Hope. ...

Then theElveslookedup, and despairednolonger; but Morgoth was filled with doubt. (S 250)

The War of Wrath is denouement only; even then, ithas value only as a preface to the dialogue between Maglor and Maedhros. It is the rising of Gil-Estel that confers the "sudden joyous "turn," "the "sudden and miraculous grace: never to be counted on to recur" (OFS 75, emphasis added), the "sudden unhoped-for happyending," and the "sudden happy turn in a story which pierces you with a joy that brings tears" (Letters 100, emphasis added). The Star appears suddenly, out of nowhere, "unlooked for," by the peoples of Middle-earth. This is their eucatastrophe, not ours or the narrator's readers, hence the immeasurably different feel from the horns of Rohan.

Thus, the chapter titled "The Voyage of Eärendil and the War of Wrath" is divided into equal halves, yet the War of Wrath in the second half has been subordinated to the Maglor-Maedhros dialogue. That structurally links the dialogue as the thematic counterpart to the Voyage of Eärendil. After the star of Gil-Estel rises, the sons of Fëanor fall.

This reading, then, explains the otherwise surprising rapidity of the War of Wrath —war matters less toournarrator than Maglor's moral truths or Eärendil's saving voyage. What, then, of narrative speed in the Túrin story?

The key might be the "suddenness" of Gil-Estelfor the people of Middle-earth. Only endless woe and long defeat can pave the way for the miraculous appearance of that last poetic image. In the six chapters priortothe War of Wrath, we witnesstales of devastation andruin punctuated by small moments of non-lasting success. Beleriand is ruined; Fingolfin perishes; the Fifth Battle is lost; Túrin is doomed; the hidden realms of Nargothrond, Doriath, and Gondolin are felled. Or, put otherwise, these tales of doom last 120 pages. The Voyage of Eärendil and the War of Wrath that follow last merely 11.

Yet the differing narrative speeds of these preceding six chapters operate against one another toheighten the reader's sense of despair forMiddle-earth—or sothenarratorintends. Thetwo "slowest"chapters focus on Beren and Túrin; the dyscastrophe of Túrin undermines the minor eucatastrophe of Beren. Yet each of these "slow" chapters is surrounded by a "fast" chapter. These fast chapters describe wide-scale destruction and tragedy. Túrin's slow, drawn-out individual 
doomfollows the rapid-firedyscastrophe of thenorthlands in the Nirnaeth Arnoediad, which itself (intentionally) undermines the minor eucatastrophe of Beren and Lúthien, which itself is only a temporary palliative to the preceding "Ruin" of Beleriand. Then, having established how theindividual doom of Túrin contributed to the social and political doom of Nargothrond, the narrator has laid the groundwork for the subsequent downfalls of Doriath and Gondolin. The narrator doesnotneed tospend as muchtime on them. Moreover, structurally, having two fast chapters follow the Túrin story (rather than one, as with "Beren and Lúthien") accentuates the sense of precipitous decline for the reader. When astatue topples, it topples slowly at the beginning; only when near the ground is its momentum the greatest. The narrator re-creates Gil-Estel's eucatastrophe by rescuing the "statue" just before it shatters forever.

Such a unified structure is lost, I suggest, if we attempt to reduce The Silmarillion to a compilation of hypotexts. Combined, these chapters are powerful. That power can be best explained by a writer-narrator's careful, guiding hand.

\section{Uniting All Five Stories}

Tomy mind, the biggest obstacle remaining to my unified text thesis is Christopher Tolkien's flat-out declaration that "the Akallabêth and Of the Rings of Power, which appear at the end, are (it must be emphasized) wholly separate and independent" from the preceding three stories ( $S$ viii, emphasis added). Yet, he says, they are "included according to my father's explicit intention" ( $S$ viii). Before I tackle this last objection in-depth, let me briefly examine one prefatory problem.

\subsection{Twice-Written Passages}

Many stories that occur in The Silmarillion happen to be "twice told." This occurs especially in the beginning of each of the five major tales. For example, the first two paragraphs in the "Valaquenta" summarize the "Ainulindalë." This apparent wordiness and repetition allegedly supports the compilation thesis because it violates the Ockham's razor theory of good prose. If a skilled writer composes a text - and I argue thatournarrator is very skilledindeed - then the writer should be skilled enough totell the story adequately the first time, especially in a purportedhistory.

The question then becomes, of course, whether this repetition actually is needless. My argument, as before, is that rather than see these twice-told passages as 
mistakes or careless repetitions in an insufficientlyedited compilation, we oughtto attend totherhetoricaleffects thesepassages haveintheirsecondtelling. Inthe "Valaquenta"opening, repeating the creation myth operates as a type of transition. It makes explicit a link between "Valaquenta" and "Ainulindalë," but the differing style - more heavily abbreviated, a more rigid narrative voice - tips the reader off on the nature of the story to follow. Rather than the fraught tension of contending wills, we will encounter a lecture and summary incorporating valuable information for later. The complete neglect of Morgoth's role in the creation, furthermore, reaffirms the fundamental original goodness of the creation. A good summary leaves out the least important tidbits; by leaving Morgoth out of the creation, the narrator corrects an impression that "Ainulindalë" may have left, that Morgoth was somehow essential to the creation. This reminder becomes necessary because the writerknows thatEru will disappear almost entirely from the rest of the text.

\subsection{The Unified Text: The Two Codas}

A major hurdle to the ultimate unity of The Silmarillion rests not only with Christopher Tolkien's denial, cited earlier, but also with the immense difference in feel between the "Quenta Silmarillion" and following story, the "Akallabêth."I doubt that Iam alone among readers in thinking that theeucatastrophicendnote of the book's majorstory feels like the end of the textentirely; it almost takes an act of will to begin the "Akallabêth." As Mary R. Bowman has pointed out, however, narrative theory has often questioned the exact nature of endings. Speaking of The Lord of the Rings, she says that the "book is denied strong closure by the presence of another structural feature, the appendices" (276). Those appendices undermine Bilbo's "happily ever after" ending andindicate, conversely, the arbitrariness of what constitutes a beginning-Appendix A shows how The Hobbit began much earlier than indicated in the actual book. Coming at the issue from a Bakhtinian perspective, the literary critic Gary Saul Morson makes a similar point. AccordingtoBakhtin, theessentialfeature of the "present" is its unfinalizability. "We sense the present... as open. We sense the past as closed, because its outcome - our own situation —is already known and determined" (Morson 87). But the sense of finalizability implied by an ending is only a fiction. Our sense of the openness of the present can extend backwards into the past; one literary way of creating this effect is to question beginnings and endings.

Thoughmany of the writer's greatest themes have already been articulated by the ending of the "Quenta Silmarillion," he must nevertheless deal with the 
onward thrust of time. History never just stops; the writermustbringhishistoryup to his present.Inthe "Akallabêth,"we see a story line roughly equivalent to what we have seen before - initial bliss, followed by hubris or self-assertiveness, and a Fall-but one in which the narrator's concerns have been subtly shifted to accommodate a new focal point. Though the writer is still tied to the past by his Elvish sympathies, he tackles a potential impediment to perfect moral goodness that was previously unimportant: the fear of death.

Weturn to the opening of the "Akallabêth."Itretells the story of Eärendil's voyage and the War of Wrath. Yet this retelling contains less doubtand sadness, fewerof the conflicts, fewerof therhetoricalflourishesmeant to heighten emotion. Being twice told, this version cannot be "sudden"; it cannot lead to eucatastrophe in the same sense. It serves a different purpose. First, rather than signaling the divine grace of a literal deus ex machina, this second telling operates as a literary tool. It foreshadows Amandil's voyage west near the story's end; Amandil intends, as both his speech and the narrator's commentarymake clear, to reenactthe "embassy" of Amandil's ancestorEärendil(S276). Amandil fails. 16 Yetbeforehefails, the narratorallows Amandil to articulate the moralcenterof "Akallabêth," a sentiment thatmight, had it been uttered by Maglor, spared that elf from doom: "I would betray the King," says Amandil, for "there is but one loyalty from which no man can be absolved in heart for any cause" (S 275). Amandil means loyalty to Ilúvatar, of course. Yetthenarrator does not permit Amandil to name Ilúvatar explicitly - because it is better to preach subtly rather than overtly, as Tolkien himself implies in the Milton Waldman letter when he notes that any explicit reference to the Christian religion would be "fatal" for fairy stories (Letters 144).

Under my reading, the major point of "Akallabêth" is to depict Númenor as different from Beleriand, the last place "upon Earth... where the memory of a time without evil is preserved" ( $S 279)$, but now cut off permanently from Aman by its own folly.Itthus serves as afundamental link between The Silmarillion's first three stories and "Of the Rings of Power and the Third Age."'The narrator's final story concerns aland that has always rememberedeviland whatsuchaland must look like. What suchalandlookslike, of course, is the narrator's own land.

Here, then, is the basic action for the five stories of the Silmarillion. The story of the Elder Days, incorporating the first three stories, ends with decline and eventually destruction. It constitutes the bulk of the entire book because the narrator must make his story plausible, especially to an audience perhaps skeptical of the author's basic moral viewpoint and ignorant of Elvish tradition (Agøy 159). The reader must be shown, step by step, the onset of the Fall from the originally blessed state. 
ThenNúmenorintheSecondAgearises. The narratorpresentshismaterialasa rapid summary because, in a sense, the same story has already beentold about the First Age. The narratorglosses over 23 kings of Númenorbecausehedoesnotreally careabout Númenoritself. ${ }^{17}$ Heisconcerned with Menas beings who are inferior to the Elves and whose fear ofdeath - ratherthantheirdesireforthefruitsoftheirlaborbecomes the instrument of their corruption by evil. The narrator's final story is both acodato "QuentaSilmarillion" and acontinuation of theFall. That Fall will be completed at the end of the Third Age, when the Elves disappearforeverinto the West. The Warof the Ring, the greatest triumph of Men-ironically accomplished by a "Halfling" - cannot really be an ultimate triumph, not when so much of beauty had been lost: a theme foreshadowed by the earlier "ultimate" triumphs overevil.

The narrator maintains his moral focus throughout his story: the subtle warnings to the readertoavoidevil becauseevil willultimately destroy itself; the affirmation that divine grace will intercede in history, though only after much sorrow; and that the single best way to handle one's fate is through humility, submission to the higher powers, and - if necessary - self-sacrifice. Whether these particular virtues are salutary or the final word must depend on the individual reader. But what is certainly magnificent about The Silmarillion is the skill and craft utilized by the book's writer to entreat — to guide, to seduce - the reader to that writer's particular vision of the Good.

\section{Conclusion}

Throughout thisessay,Ihaveargued against the "compilation"or"lost texts" thesis. Both lead to reading The Silmarillion as a flawed or inconsistent work, valuable only for its echoes of an ancient literary past yet and ultimately superseded by Unfinished Tales and theHistory of Middle-earth. Such a view, Ibelieve, does a disservice to the published 1977 text. For my part, as a reader, I havenever felt the lack of any narrative framing device to be a lack - and the lack of that narrative framework, I maintain, means that we must radically reread The Silmarillion, even in ways not intended by the author. Nor can we simply ignore this problem; as argued in section 2.1, the 1977 text oughtbe accorded a special, privileged status not likewise accorded Tolkien's other posthumous publications. It is a King Lear-type of conflated text, never specifically authorized by the author but greater than the individual versions produced by him. Ultimately, the "unified text" thesis holds that all the pieces within the published Silmarillion fit together, have meaning, and relate to a larger wholeregardless of whether individual passages may be traced verbatim to "earlier" texts. 
Section 3 examined the great rhetorical skill apparent within two passages. Section 4 looked at the diversity of narrative speeds within the "Quenta Silmarillion" and showed how, assuming great rhetorical skill, this diversity might extend and deepen the overall effect. The final section, section 5.2, argued for the structural and thematic unity between all five stories in The Silmarillion.

Closely tied to the "unified text" thesis is the idea that, within the textual world, a writer-narrator must have written this unified text and intended its higher meaning. We know nothing about him beyond what may be gleaned fromhis composition. As Nils Ivar Agøy has suggested, this narrator is probably a Man speaking to a Mannish audiencethatknows littleofElvish tradition; the narrator mustcomefrom the Fourth Age or later (159). To these characteristics, I have added "extreme rhetorical skill" and a "moral viewpoint of high seriousness." More concerned with ethical knowledge than with "true history," this writer-narrator aims to lead his audience to the Good Life, the life rightly led-rectitude in the face of tragedy, humility toward God or the gods. Iwould diverge from Agøy, though, by refusing to equate the narrator's voice with Tolkien's own. As most narrative theory holds, and as Paul Edmund Thomas says, the "narrator's voice is not and cannot be precisely equivalent to Tolkien's voice, because Tolkien stands both inside and outside thenovel"(162).Ournarratormay share Tolkien'smoral earnestness and "silvertongue,"butthey arenot the same.

Letme close with a suggestion. Previously, I compared the Silmarillion's narrator to Geoffrey of Monmouth, but another appropriate comparison might be the ancient Greek writer Xenophon. Alongside Plato, Xenophon was the only student of Socrates to write about Socrates. Todayhis reputation as a writertends to be low: philosophers dismiss his philosophy, historianshis history. YetXenophon never considered himself a philosopher or a historian. He called himself an "orator," a man who possessed the art of public speaking, of adapting speech to audience. He used his arttoteach his audience virtue. Poetry, Aristotlehad said, is a higher art than history. The historian is limited to the world-asit-is, but the poet can depict the worldas-it-ought-to-be. Sir Philip Sydney had called Xenophon a Poet. For our purposes, in our text, the narrator of the 1977 Silmarillion is neither philosopher nor historian but a Xenophonic Poet—a moralist, a rhetorician, an orator-in-writing.

\section{Notes}

1. Inotherwords, the 1977textfascinates Kanebutnotasmuchas a hypothetical, finished-but-unaltered text. Compare the much more dismissive Rosebury: "The absence of the distinctive virtues of The Lord of the Rings - the 
exhilarating, expansive realization of Middle-earth, the unified plot whose excitements are integrated with that realization, the transparent prose which is the medium forboth - has made The Silmarillion a confesseddisappointment to many,perhapsmost, of theadmirers wonforTolkienby theearlier-published work" (103).

2. VerlynFliegernotesthat, whereasEliasLönnrotprovidedTolkien apersonal modelforhismythology, Lönnrotworked his textsover so heavily that they no longer seemed to denote a properly folkloric past. The Arthurian romances, in contrast,provided abetter textual model, showing Tolkien a "multilayered and ongoing process" where "the material was cast first as poetry and then, to validate its authenticity, recast as prose" (39). Both these points give credence to the compilation thesis. In contrast, I argue that the 1977 text has been heavily worked over by a single author - to the point where it has achieved "unity" and its parts interlock.

3. A partial listing of references include the Aldudénië (S 76), the Maglorcomposed Noldolantë (S 87), the Lay of Leithian (S 162), the Narn i Hîn Húrin (S 198), the Laer Cú Beleg (S 209), the Fall of Gondolin (S 242), the Lay of Eärendil (S 246, 259), etc. We have several allusions to sources notnamed, most often indicated by the phrase "it is told" $(S 43,53,98)$, "it is said" $(S 54,276)$, or "some hold that" ( $S 285)$. Sometimes, The Silmarillion evencomplicatesthe issue. The Túrin story, for example, is here in this text "told in brief" but elsewhere "full told" (S 198-99) — which, as Gergely Nagy points out, indicates that the Túrin story is therefore "a compressed retextualization of anothertext. Thisis where depthisagaincreated by aclaimofaunknowntextanda corresponding textual relation" ("Great Chain" 243). Nonetheless, there does exist evidence that someone has set his or her hand editing these stories. The final story, "Of the Rings of Power and the Third Age," references stories given earlierin the book - the "Quenta Silmarillion" $(S 286)$ and the "Akallabêth" $(S$ 290). Otherphrases, such as "as has been told," referto information given in previous chapters. Weeven have one reference in "Akallabêth" about Sauron (S 267) to the following story in the book, "Of the Rings of Power."

4. Nagy unpacks the textual complexities when henotes that The Silmarillion is a precursor of Lord of the Rings and offers it context and that itallows ustoboth comprehendandinterpretthe allusionsin Lord of the Rings. But within The Silmarillion's textual world, Túrin's storyenjoysits own textual history-itis a compressed rewriting of earlier texts existing within that textual world itself ("Great Chain" 243).

5. She makes this point of Lord of the Rings, but I think it applies doubly to The 


\section{Silmarillion.}

6. "Hypotext" is the term used by the French narrative theorist Gérard Genette, "avant-texte" the term used by French genetic criticism. Indeed, when Vladimir Brljak denies that the History of Middle-earth is a "literary work," he does so on the grounds that its only interest lies in "genetic criticism" (24). 7. Let me admit a possible bias. I approach The Silmarillion as a literary critic of 20th-century literature - not as a medievalist. For that reason, seeing the textasa "story aboutstories"may simply strike meas less exciting than itdoes others. Of course, the charge of bias may always be reversed, though it may be answered that such biases mirror Tolkien'sown.

8. This sentence, in fact, provides a wonderful test case for the compilation thesis versus the unified text thesis. The phrase "at last" constitutes a clear editorial addition by Christopher Tolkien; the original passage from the 1937 "Quenta Silmarillion" simply read, "Yet he yielded to the will of Maidros" (Lost Road 330). The change is so small, in fact, that Douglas Charles Kane does not even consider it worthy of mention in Arda Reconstructed - yet this slight change affects the meaning of the passage as a whole, sinceit now becomes apparent that, in the 1977 text, Maglorneeded convincing by Maedhros, whereas the 1937 text permits us to believe that Maglor capitulated without timeconsuming argument and discussion. The compilation thesis might suggest that "at last" is simply an interpolation by the editor (which, of course, it is). If so, we could justifiably discount it as "inauthentic." This, then, changes theinterpretation:the textnolongersoclearly "hides"Maedhros's successful-yet-immoral arguments, since maybe he never makes any such arguments at all. Maglor might have capitulated for other reasons. The unified text thesis, however, argues that wemust accept the 1977 text exactly as we find it. This "at last," interpolation thoughit be, indicates that some time passes, theevents for which go undescribed by the text. My reading, I believe, has one strong advantage. Whereasthecompilation thesismightsee "atlast" as a flaw, a regrettable error by a careless scribe (perhaps), the unified text theory sees this "flaw" as creating a whole new text-something that creates, enlarges, and deepens the meaning of the whole, whichmustbe accounted for as is. The "narrator" of The Silmarillion then becomes, therefore, a type of hypothetical construct useful for explaining what otherwise might be seen as a frustrating or inauthentic interpolation.

A similar issue crops up later in the chapter: "They knew that those jewels could not be found or brought together again unless the world be broken and remade" (S 254). Kane criticizes ChristopherTolkien for putting "unless" instead of "until," which is what the source text has-Kane disapproves 
of the editor excising the Second Prophecy of Mandos (234). Now, if literary critics were to ask, "What was Tolkien's original intention?" then perhaps Kane's criticism is valid. (Even so, I would counter that "original intent" is a red herring here.) And yet, if literary critics instead ask, "How ought we to read this new text physically in front of us?" then Kane's qualms fail to have any genuine bearing on the issue. For some reason, ourhypothetical narrator wanted to write "unless." It then becomes our job as readers to figure out why. Nor can we simply ignore the 1977 book since, as I argued in section 2.1, The Silmarillion is a vital part of Tolkien's corpus.

9. Concerning one philosophical story in the History of Middle-earth, David Bratman praises Tolkien for avoiding the argumentative "trick found so often in bad novels in which the 'wrong' character offers only easily dismissed strawman arguments" (76). Let me hasten to say that Idonotconsider the Maglor passage a "trick" in any sense. Instead, let me suggest that the narrator simply shares Tolkien's trait of placing "rhetorical approval behind those characters with whom he agrees" (Saxton 172).

10. I have spelled out the argument at length, but the unreliability of premodern historians is relatively well-known. Prior to the 19th century, most historians did not think the purpose of writing history was to uncover facts. Indeed, facts-by themselves - were quite unimportant. Andrew Hadfield says that the prime difficulty for writing his biography of Edmund Spenser was that "in the sixteenth century lives of even quite prominent people only really mattered when they told a useful, moral story that could be applied with profit to the reader's own case" (1). Biographies contemporary to Spenser were "made to fit obviously useful patterns" and tended "to conform tofamiliar narratives" (2). I suggest that the "lives" of Maglorand Maedhros are intentionally made to fit one of these familiar narratives.

11. It certainly was not within Tolkien's moral compass. Bilbo refused to shed Gollum's blood, and Frodo wanted to let Saruman depart in peace from the Shire, despite Saruman's crimes.

12. Christopher Tolkien also refers to the "Valaquenta's" "continual shifting of tense and viewpoint, so that the divine powers seem now present and active in the world, now remote, a vanished order known only to memory" (ix). Such shifting helped lead Agøy to his unenthusiastic hypothesis of two narrators voicing different perspectives from different points of time (152). This section focuses on narrative speed rather than shifting tense and viewpoint, mostly due to space limitations, but my points on narrative speed would apply as well.

13. When Drout et al. discuss styles, they mostly mean stylistic variation. 
"Segments of a text may differ in vocabulary (both content and function words), sentence length or structure, repetition or avoidance of rhyme and alliteration, and other linguistic features" (184), all of which suggest interpolation or pseudointerpolation to them. This section uses "style" to discuss an idea somewhat larger thanlinguisticfeatures, namely, thelevelof detail offered and the various paces at which the narrative moves.

14. Drout does not use the word "flawed," but I think it implied. The narration creates a "verydifferentemotionaleffect than thehorns ofRohan"(44), andhefeels compelled todefendhisreading as a personal idiosyncrasy (45). 15. Nonetheless, theentire WarofWrath scene, itmustbesaid, comes nearly unaltered from Tolkien's own manuscript for the conclusion of the 1937 "earlier Quenta."Hispost-Lord of the Rings emendations, published in The War of the Jewels, are slight.

16. Well, the narrator first says without qualification that Amandil fails ( $S$ 276) but later hedges his bets - speculating that Amandil may have nonetheless succeeded (279). The narrator has no evidence of this, of course, as he himself has admitted earlier, but throwing this possibility out there reaffirms the possibility of divine grace, by now expected by the reader.

17. Here is justone of many places where my reading clashes with the compilation thesis. In Unfinished Tales, we are told that the peoples of Gondor and Imladris did not bother preserving documents aboutNúmenor,since"all butafewregarded study of whatwasleft of its history as vain, breeding onlyuseless regret"(165). The compilation thesis would say that the narrator glosses over the 23 kings because he lacks good sources for them. Yet I have argued (see section 3) that lacking sources would not have stopped the narrator haditservedhislarger purpose to write about this subject. His admitted lack of knowledge about Amandil's fate, likewise, does not stop him fromspeculating.

\section{Works Cited}

Agøy,Nils Ivar. "Viewpoints, Audiences, and Lost Texts in The Silmarillion."

The Silmarillion:Thirty Years On.Ed. Allan Turner.Zurich:

Walking Tree, 2007.139-63.

Bowman, Mary R. "TheStory Was Already Written: Narrative Theory in The Lord of the Rings." Narrative 14.3 (2006): 272-93.

Bratman, David. "The Literary Value of The History of Middle-earth."

Tolkien's Legendarium: Essays on the History of Middle-earth.Ed. 
Verlyn Flieger and Carl F. Hostetter. Westport, CT: Greenwood, 2000. 69-91.

Brljak, Vladimir."TheBooksofLostTales:Tolkienas Metafictionist."

Tolkien Studies 7 (2010): 1-34.

Drout, Michael D. C. "J.R.R. Tolkien's Medieval Scholarship and Its

Significance.” Tolkien Studies 4 (2007): 113-76.

_. "Reflections on Thirty Years of Reading The Silmarillion." The

Silmarillion:Thirty Years On. Ed. Allan Turner.Zurich: Walking

Tree, 2007.33-57.

Drout, Michael D. C., Namiko Hitotsubashi, and Rachel Scavera. "Tolkien's

Creation of the Impression of Depth.” Tolkien Studies 11 (2014): 167211.

Fisher,Jason. "From Mythopoeia to Mythography:Tolkien,Lönnrot, and Jerome.” The Silmarillion: Thirty Years On.Ed. Allan Turner.Zurich:

Walking Tree, 2007. 111-38.

Flieger, Verlyn.Interrupted Music: The Making of Tolkien's Mythology.Kent, OH: Kent State University Press, 2005.

Hadfield, Andrew. Edmund Spenser: A Life. Oxford: Oxford University Press, 2012.

Jankulak, Karen. Geoffrey of Monmouth. Cardiff: University of Wales Press, 2010.

Kane, Douglas Charles. Arda Reconstructed: The Creation of the Published Silmarillion. Bethlehem, PA:Lehigh University Press, 2009.

Morson, Gary Saul. "Time and Intelligentsia: A Patchwork in Nine Parts, with Loopholes." The Emperor Re-dressed: Critiquing Critical Theory. Ed. Dwight Eddins. Tuscaloosa: University of Alabama Press, 1995. 81-100.

Nagy, Gergely. “The Adapted Text:The LostPoetry of Beleriand.” Tolkien Studies 1 (2004): 21-41.

"The Great Chain of Reading: (Inter-)textual Relations and the Technique of Mythopoesis in the Túrin Story." Tolkien the Medievalist. Ed.JaneChance. New York: Routledge, 2003.239-58.

Noad, Charles E. "On the Construction of 'The Silmarillion.'"Tolkien's

Legendarium: Essays on the History of Middle-earth. Ed. Verlyn

Flieger and Carl F. Hostetter. Westport, CT: Greenwood, 2000. 31-68.

Rosebury, Brian. Tolkien: A Cultural Phenomenon. New York: Palgrave Macmillan, 2003.

Saxton, Benjamin. "Tolkien and Bakhtin on Authorship, Literary Freedom, and 
Alterity." Tolkien Studies 10(2013): 167-83.

Thomas, Paul Edmund. "Some of Tolkien's Narrators." Tolkien's Legendarium: Essays on the History of Middle-earth.Ed. VerlynFlieger and CarlF. Hostetter. Westport, CT: Greenwood, 2000.161-82.

Tolkien, Christopher. Foreword to The Silmarillion. By J.R.R. Tolkien. Ed. Christopher Tolkien. 2nd ed. Boston: Houghton Mifflin, 2001. Tolkien, J.R.R. 'The Story of Kullervo' and Essays on Kalevala." Ed. Verlyn Flieger. Tolkien Studies 7 (2010): 211-78.

Turner, Allan. Preface to The Silmarillion:Thirty Years On.Ed. Allan Turner. Zurich: Walking Tree, 2007. i-iv. 